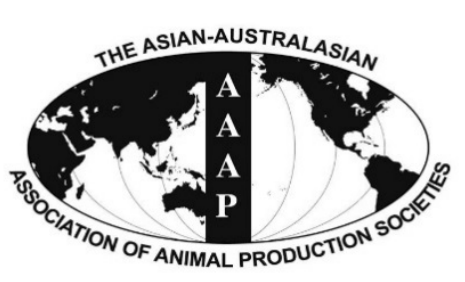

Open Access

Asian Australas. J. Anim. Sci.

Vol. 28, No. 11 : 1629-1640 November 2015

http://dx.doi.org/10.5713/ajas.15.0128

www.ajas.info

pISSN 1011-2367 elSSN 1976-5517

\title{
Comparison of Carcass and Sensory Traits and Free Amino Acid Contents among Quality Grades in Loin and Rump of Korean Cattle Steer
}

\author{
Min Yu Piao', Cheorun Jo ${ }^{1,2}$, Hyun Joo Kim ${ }^{1}$, Hyun Jung Lee ${ }^{1}$, Hyun Jin Kim¹, \\ Jong-Youl $\mathrm{Ko}^{3}$, and Myunggi Baik ${ }^{1,2, *}$ \\ ${ }^{1}$ Department of Agricultural Biotechnology and Research Institute of Agriculture and Life Sciences, \\ College of Agriculture and Life Sciences, Seoul National University, Seoul 151-921, Korea
}

\begin{abstract}
This study was performed to compare carcass traits, sensory characteristics, physiochemical composition, and contents of nucleotides, collagen, and free amino acids among quality grades (QG) and to understand the association between QG and above parameters in loin and rump of Korean cattle steer. Loin and rump samples were obtained from 48 Korean cattle steers with each of four QG (QG 1++, 1+, 1, and 2; average 32 months of age). Carcass weight and marbling score (MS) were highest in QG 1++, whereas texture score measured by a meat grader was highest in QG 2. A correlation analysis revealed that $\mathrm{MS}(\mathrm{r}=0.98 ; \mathrm{p}<0.01)$ and fat content $(\mathrm{r}=0.73 ; \mathrm{p}<0.01)$ had strong positive correlations with $\mathrm{QG}$ and that texture had a strong negative correlation $(\mathrm{r}=-0.78)$ with $\mathrm{QG}$. Fat content in loin was highest but protein and moisture contents were lowest in QG 1++. Our results confirmed that a major determinant of QG is the MS; thus, intramuscular fat content. The International Commission on Illumination $\mathrm{L}^{*}, \mathrm{a}^{*}$, and $\mathrm{b}^{*}$ values in loin were highest in QG 1++. Numeric values of shear force in loin were lowest in QG 1++, whereas those of tenderness, juiciness, and overall acceptability tended to be highest in QG 1++ without statistical significance. QG was strongly correlated with juiciness $(\mathrm{r}=0.81$; $\mathrm{p}<0.01)$ and overall acceptability $(\mathrm{r}=0.87 ; \mathrm{p}<0.001)$. All sensory characteristics were higher $(\mathrm{p}<0.05)$ in loin than those in rump. Adenosine-5'-monophosphate (AMP) and inosine-5'-monophosphate (IMP) contents in both loin and rump did not differ among QGs. No nucleotide (AMP, IMP, inosine, hypoxanthine) was correlated with any of the sensory traits. Total, soluble, and insoluble collagen contents in loin were higher in QG 1++ than those in QG 1. All three collagens had lower content in loin than that in rump. All three collagens were positively correlated with tenderness, juiciness, and overall acceptability. Glutamic acid content did not significantly differ among the four QGs in either loin or rump. In conclusion, it is confirmed that QG is associated with sensory traits but nucleotide contents in beef may not be a major factor determining meat palatability in the present study. (Key Words: Korean Cattle Steers, Carcass Traits, Quality Grades, Loin, Rump)
\end{abstract}

\section{INTRODUCTION}

Quality grade $(\mathrm{QG})$ in the Korean beef quality grading system is divided into five grades (QG 1++, 1+, 1, 2, and 3), where QG $1++$ is the highest grade, and QG 3 is the lowest grade. The QG of beef in Korea is based on the marbling

\footnotetext{
* Corresponding Author: Myunggi Baik. Tel: +82-2-880-4809, Fax: +82-2-873-2271, E-mail: mgbaik@snu.ac.kr

${ }^{2}$ Institute of Green Bio Science Technology, Pyeungchang 232-

916, Korea.

${ }^{3}$ National Agricultural Cooperative Federation, Anseong 456824 , Korea.

Submitted Feb. 12, 2015; Revised Apr. 28, 2015; Accepted May 22, 2015
}

score (MS), fat color, meat color, texture, and maturity of the longissimus dorsi muscle at the 13th rib interface (National Livestock Cooperatives Federation, 1998). Of the 421,464 Korean cattle steer carcasses slaughtered in 2013, $17.1 \%$ were QG $1++, 32.7 \%$ were QG $1+, 33.9 \%$ were $Q G$ $1,15.0 \%$ were QG 2 , and $1.2 \%$ were QG 3 (KAPE, 2013). There are large differences in market price of beef among QGs in Korean cattle. For example, the price of QG 1++ Korean cattle beef in 2013 was 2.1-fold higher than that of QG 3 (KAPE, 2013). Thus, Korean farmers have been made an effort to obtain good QGs (QG 1++ and QG 1+) to earn more income. As free-trade agreement negotiations have increased with other countries, Korean farmers have 
become more concerned about price competition between Korean cattle beef and imported beef.

Sensory characteristics, including tenderness, flavor, and juiciness, are important determinants of acceptability and palatability of beef (Savell et al., 1987). A consumer survey revealed that tenderness is the most important factor in consumer eating satisfaction, followed by flavor and juiciness (Huffman et al., 1996). In Korea, These three factors also account for 55\%, 27\%, and $18 \%$, respectively (Cho et al., 2011). Increased cross-links in collagen fibrils (connective tissue) may contribute to increased toughness as the animal matures (Shorthose and Harris, 1990). In terms of meat flavor perception, 5'-ribonucleotides, adenosine monophosphate (AMP) and inosine monophosphate (IMP) can be considered as important factors because they cause umami taste characteristics (Durnford and Shahidi, 1998).

Beef MS and QGs positively affect meat sensory characteristics, including tenderness, juiciness, flavor, and overall palatability (Savell et al., 1987). It has been thought that the palatability of Korean cattle beef is good because of the high QG and thus high MS. Limited information is available and variability exists in data on the associations among MS/QG, meat characteristics, and sensory traits in Korean cattle beef. In this study, we compared carcass traits, sensory characteristics, and free amino acid content among QGs in loin and rump of Korean cattle steer. The associations among QGs and various carcass characteristics and sensory traits were also evaluated.

\section{MATERIALS AND METHODS}

\section{Animals and sampling}

Korean cattle steer were reared on a commercial farm (Yeongam-gun, Jeollanam-do, South Korea) according to the traditional Korean cattle feeding system. Briefly, Korean cattle bulls were weaned at 3 months of age and were then fed roughage (70\%) and concentrate $(30 \%)$ until 5 months of age. The bulls were castrated at 6 months of age, and steers were grown in pens (five steers/pen; pen size, $5 \times 10 \mathrm{~m}$ ) using group feeding. The steers were fed a total mixed ration (TMR) twice daily until slaughter at around 32 months of age. The TMRs were formulated to fit growing (7 to 12 months of age) and three fattening stages (early fattening, 13 to 18 months of age; middle fattening, 19 to 24 months of age; and late fattening, 25 months of age to slaughter, Table 1). The formula and chemical composition of the protein and energy concentrates used in the TMR are shown in Table 2. All steers had free access to water and mineral salt blocks.

The Korean cattle steers were transported to the NongHyup Naju joint livestock products market (Naju, Korea), fasted for $24 \mathrm{~h}$, but given free access to water. The animals
Table 1. Ingredient and chemical composition of the total mixed ration for Korean cattle steers

\begin{tabular}{|c|c|c|c|c|}
\hline Item & $\begin{array}{c}\text { Growing } \\
\text { period }\end{array}$ & $\begin{array}{c}\text { Fattening } \\
\text { period } \\
\text { (early) }\end{array}$ & $\begin{array}{c}\text { Fattening } \\
\text { period } \\
\text { (middle) }\end{array}$ & $\begin{array}{c}\text { Fattening } \\
\text { period } \\
\text { (late) }\end{array}$ \\
\hline \multicolumn{5}{|c|}{ Ingredient, $\%$ (as-fed basis) } \\
\hline Molasses & 3.74 & 3.75 & 3.71 & 3.37 \\
\hline Corn, flaked & 0.00 & 4.41 & 7.42 & 14.79 \\
\hline Cotton seed & 0.00 & 2.65 & 2.97 & 3.63 \\
\hline Rice straw & 0.00 & 6.62 & 7.42 & 9.60 \\
\hline Timothy, hay & 5.98 & 0.00 & 0.00 & 0.00 \\
\hline Sugar beet pulp & 4.48 & 4.41 & 4.95 & 2.59 \\
\hline Italian ryegrass silage & 11.96 & 6.62 & 6.68 & 0.00 \\
\hline Alfalfa, hay & 7.47 & 0.00 & 0.00 & 0.00 \\
\hline Liquid microbes & 0.20 & 0.20 & 0.20 & 0.20 \\
\hline $\mathrm{NaHCO}_{3}$ buffer & 0.00 & 0.30 & 0.30 & 0.35 \\
\hline Ryegrass straw & 4.48 & 6.62 & 3.71 & 0.00 \\
\hline Protein concentrate & 24.36 & 20.96 & 18.55 & 12.97 \\
\hline Energy concentrate & 0.00 & 4.41 & 8.16 & 15.57 \\
\hline Brewers grain, wet & 8.07 & 8.16 & 7.42 & 7.26 \\
\hline Lupin hull & 13.45 & 13.24 & 9.90 & 7.26 \\
\hline Oats, hay & 4.48 & 0.00 & 0.00 & 0.00 \\
\hline Water & 11.31 & 17.65 & 18.60 & 22.39 \\
\hline \multicolumn{5}{|c|}{ Chemical composition (\% DM) } \\
\hline Dry matter $(\mathrm{DM})$ & 67.21 & 64.87 & 64.50 & 65.84 \\
\hline Crude protein & 15.67 & 14.42 & 14.12 & 13.13 \\
\hline Crude fat & 3.44 & 4.09 & 4.42 & 4.78 \\
\hline Crude fiber & 22.86 & 20.54 & 18.45 & 15.26 \\
\hline Crude ash & 6.88 & 6.85 & 6.56 & 5.89 \\
\hline NFE & 51.14 & 54.11 & 56.45 & 60.95 \\
\hline NDF & 54.51 & 51.47 & 47.15 & 39.26 \\
\hline $\mathrm{ADF}$ & 33.15 & 31.92 & 29.33 & 24.35 \\
\hline TDN & 70.78 & 74.01 & 75.32 & 78.22 \\
\hline
\end{tabular}

NFE, nitrogen-free extract; NDF, neutral-detergent fiber; ADF, aciddetergent fiber; TDN, total digestible nutrient.

were slaughtered the next day, and the carcasses were moved to a cold room at $5^{\circ} \mathrm{C}$. The carcasses were graded based on the Korean grading standard the following day. At this stage, carcass weight, longissimus muscle (LM) area, fat thickness, MS, yield index, yield grade, meat color, fat color, texture, and maturity were examined and reported by an official meat grader.

Forty-eight loin and lump tissues (about $500 \mathrm{~g}$ ) with 12 samples from each four QGs (QG 1++, 1+, 1, and 2) were collected from 48 Korean cattle steers, transported under ice $\left(4^{\circ} \mathrm{C}\right)$ to a laboratory $24 \mathrm{~h}$ postmortem, and kept at $-80^{\circ} \mathrm{C}$ for 1 week. The samples were thawed at $4^{\circ} \mathrm{C}$ for 1 day before analysis. The beef samples were minced using a mini chopper (CH180, Kenwood, Shanghai, China) for $30 \mathrm{~s}$, and excess connective and fat tissues were removed before weighing. A part of the meat sample were aged further at $4^{\circ} \mathrm{C}$ for 7 days as part of the free amino acid analysis because fresh tissue has low free amino acid content. 
Table 2. Ingredient and chemical composition of energy and protein concentrates

\begin{tabular}{lcc}
\hline Item & $\begin{array}{c}\text { Energy } \\
\text { concentrate }\end{array}$ & $\begin{array}{c}\text { Protein } \\
\text { concentrate }\end{array}$ \\
\hline Ingredient, \% (as-fed basis) & & \\
Corn & 60.00 & 0.05 \\
Wheat flour & 3.00 & 5.00 \\
Palm kernel meal & 5.00 & 20.00 \\
Dried distillers grains with solubles & - & 4.85 \\
Corn gluten feed & - & 24.00 \\
Rapeseed meal & - & 6.10 \\
Molasses & - & 5.00 \\
Rumen protected fat (Ca soup) & 3.00 & - \\
Condensed molassed soluble & - & 2.00 \\
Lupin, flake & 19.00 & - \\
Wheat bran & 10.00 & 5.00 \\
Coconut meal & - & 20.00 \\
Sesame meal & - & 8.00 \\
Chemical composition, \% DM & & \\
Dry matter (DM) & 89.12 & 89.07 \\
Crude protein & 14.12 & 23.58 \\
Crude fat & 6.95 & 4.65 \\
Carbohydrate & 75.91 & 65.02 \\
Crude ash & 3.03 & 6.75 \\
Crude fiber & 7.19 & 12.17 \\
Ca & 0.65 & 0.30 \\
P & 0.35 & 0.74 \\
NDF & 17.98 & 41.46 \\
ADF & 9.48 & 20.16 \\
TDN & 90.71 & 80.84 \\
\hline
\end{tabular}

NDF, neutral-detergent fiber; ADF, acid-detergent fiber; TDN, total digestible nutrient.

Minced beef samples were taken from various locations and pooled for analyses.

\section{Proximate composition}

Moisture, crude protein, and crude fat contents were analyzed according to AOAC methods (AOAC, 1996).

\section{Cooking loss}

Cooking loss was determined as the percentage weight loss of a meat sample (60 g) after cooking (Jung et al., $2013 b$ ). Three replicate samples from each animal were separately sealed in polyethylene bags, heated in a water bath at $75^{\circ} \mathrm{C}$ for $30 \mathrm{~min}$, and cooled at room temperature for $30 \mathrm{~min}$.

\section{Shear force}

Maximum shear force $(\mathrm{kg})$ was measured according to the method described by Kim and Lee (2003) with some modifications. Each replicate cooking loss sample was cut into a $1.0 \times 1.0 \times 1.5-\mathrm{cm}$ shape. Shear force was measured using a Warner-Bratzler shear attachment on a texture analyzer (CT3 10K, Brookfield Engineering Laboratories, Middleboro, MA, USA) with a $10-\mathrm{kg}$ load cell and 2.0 $\mathrm{mm} / \mathrm{min}$ cross-head speed. Each replicate was sheared once across the center of the sample perpendicular to the muscle fibers.

\section{pH}

The samples (10 g) were homogenized (T10 basic, Ika Works, Staufen, Germany) with distilled water $(90 \mathrm{~mL})$ at $1,130 \times \mathrm{g}$ for 1 min. $\mathrm{pH}$ of the loin meat was measured using a pH meter (SevenGo, Mettler-Toledo International Inc., Schwerzenbach, Switzerland).

\section{Color}

Surface-color values (International Commission on Illumination [CIE] $\mathrm{L}^{*}, \mathrm{a}^{*}$, and $\mathrm{b}^{*}$ values representing lightness, redness, and yellowness, respectively) were measured using a colorimeter (CR-310, Minolta Co., Ltd., Osaka, Japan).

\section{Nucleotide content}

Nucleotide content was determined according to Jung et al. (2013a). Minced samples (5 g) were mixed with $20 \mathrm{~mL}$ $0.7 \mathrm{M}$ perchloric acid and homogenized to extract nucleic acids. The homogenate was centrifuged (Union 32R, Hanil Co., Ltd., Seoul, Korea) at 2,290 $\times \mathrm{g}$ for $15 \mathrm{~min}$ at $4{ }^{\circ} \mathrm{C}$, filtered through filter paper (Whatman No. 4, Whatman PLC, Maidstone, UK), and the supernatant was adjusted to pH 5 (SevenGo, Mettler-Toledo International Inc., Switzerland) with $7 \mathrm{~N} \mathrm{KOH}$. The supernatant was placed in a volumetric flask and adjusted to $50 \mathrm{~mL}$ with $0.7 \mathrm{M}$

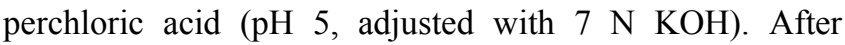
cooling for $30 \mathrm{~min}$, the mixture was centrifuged at 3,000 rpm for $15 \min \left(4^{\circ} \mathrm{C}\right)$, and the supernatant was analyzed by high-performance liquid chromatography (HPLC) (Ultimate 3000, Dionex, Sunnyvale, CA, USA). The analytical conditions for HPLC included a Synergi Hydro-RP $80 \AA$ $(250 \times 4.6 \mathrm{~mm}, 4-\mu \mathrm{m}$ particles; Phenomenex Inc., Seoul, Korea) column eluting $20 \mathrm{mM}$ potassium phosphate monobasic $(\mathrm{pH} \mathrm{5)}$ at a $1.0 \mathrm{~mL} / \mathrm{min}$ flow rate. Injection volume was $10 \mu \mathrm{L}$, and elution time was $25 \mathrm{~min}$. Column temperature was maintained at $30^{\circ} \mathrm{C}$, and detection was monitored at a wavelength of $254 \mathrm{~nm}$. Nucleotide content was determined from a standard curve obtained using the standards AMP, IMP, inosine, and hypoxanthine (Sigma Aldrich, St. Louis, MO, USA) and calculated by area under each peak.

\section{Total and insoluble collagen contents}

Total and insoluble collagen contents were measured according to the modified methods of Jayasena et al. (2013). Sample contents were determined after hydrolyzing $1 \mathrm{~g}$ of 
meat with $25 \mathrm{~mL}$ of $6 \mathrm{M} \mathrm{HCl}$ at $110^{\circ} \mathrm{C}$ for $16 \mathrm{~h}$. The hydrolysates were neutralized to $\mathrm{pH} 2$ to 6 with $6 \mathrm{M} \mathrm{NaOH}$ and diluted to $500 \mathrm{~mL}$ with distilled water. The hydrolysate (4 mL) and $2 \mathrm{~mL}$ of chloramine $\mathrm{T}$ solution (1.41-g chloramine T, $10 \mathrm{~mL}$ distilled water, $10 \mathrm{~mL} \mathrm{1-propanol,} \mathrm{and}$ $80 \mathrm{~mL}$ citric buffer; $\mathrm{pH} \mathrm{6)}$ were mixed in a test tube and left for $20 \mathrm{~min}$ at room temperature. Next, $2 \mathrm{~mL}$ of 4-dimethylaminobenzaldehyde (DABA) solution (10g DABA, $35 \mathrm{~mL}$ $60 \%$ perchloric acid, and $65 \mathrm{~mL}$ 2-propanol) were added. The solutions were shaken and heated at $60^{\circ} \mathrm{C}$ for $60 \mathrm{~min}$. The samples were cooled for $5 \mathrm{~min}$ in tap water and absorbance measured at $558 \mathrm{~nm}$. Hydroxyproline content was determined from a standard curve, and collagen content was calculated from hydroxyproline content using the coefficient 8.

Samples $(5 \mathrm{~g})$ to determine insoluble collagen content were homogenized with $24 \mathrm{~mL}$ Ringer's solution (1 L distilled water, $8.6 \mathrm{~g}$ sodium chloride, $0.3 \mathrm{~g}$ potassium chloride, and $0.33 \mathrm{~g}$ calcium chloride) and diluted 1:3 with distilled water. The homogenates were heated for $70 \mathrm{~min}$ at $77^{\circ} \mathrm{C}$ and centrifuged at $2,300 \mathrm{rpm}$ for $30 \mathrm{~min}$. The sediment was mixed with $24 \mathrm{~mL}$ diluted Ringer's solution and centrifuged again. Next, the sediment was dried at $105^{\circ} \mathrm{C}$, and the dried mass was hydrolyzed with $25 \mathrm{~mL}$ of 6 $\mathrm{M} \mathrm{HCl}$. Collagen content of the sediment was determined as described for total collagen.

\section{Free amino acids}

The free amino acid composition was determined by modifying the methods described by Jayasena et al. (2014). A defatted meat sample $(5 \mathrm{~g})$ was mixed with $20 \mathrm{~mL}$ of $2 \%$ TCA solution and homogenized at 13,500 rpm for $1 \mathrm{~min}$. The homogenate was centrifuged for $15 \mathrm{~min}$ and filtered through $0.45 \mu \mathrm{m}$ membrane filter. The filtrate was derivatized using the Waters AccQ-Tag method (Millipore Co., Milford, MA, USA), and $5 \mu \mathrm{L}$ were injected into a reverse phase-HPLC (AccQ Tag column, 3.9×150 mm; Waters). The column temperature was $37^{\circ} \mathrm{C}$, and a fluorescence detector (Waters 2475) was used with 250- and 395-nm excitation and emission wavelengths. Separation was performed using a gradient of buffers: A (Waters AccQ Tag eluent) and B (60\%, v/v, acetonitrile).

\section{Sensory evaluation}

Beef samples were cut into sections $(20 \times 50 \times 20 \mathrm{~mm})$ and cooked on a preheated clam-type electric grill featuring double heating surfaces (1,400 W, Nova EMG-533, Evergreen Enterprise, Seoul, Korea). The internal temperature was monitored using a digital thermometer (YF-160A Type-K; YFE, Hsinchu City, Taiwan) placed in the center of the meat sample; the samples were removed from the grill after they reached an internal temperature of $72^{\circ} \mathrm{C}$. Samples were assessed for their appearance, odor, taste, flavor, texture, juiciness, and overall acceptability. A 9-point hedonic scale, where 9 indicates "extremely like" and 1 indicates "extremely dislike," was employed for evaluating all the parameters. The samples were placed on transparent plastic white dishes and labeled randomly with a 3 -digit numerical code. All samples were provided to each of the panelists along with drinking water for rinsing their oral cavity following testing of each sample. This procedure of sensory evaluation was conducted in three independent experiments.

\section{Statistical analyses}

The carcass characteristics, chemical compositions, physicochemical traits, sensory evaluation, nucleotide composition, collagen content, and free-amino acid data were analyzed by analysis of variance using SAS software (SAS Institute, Cary, NC, USA), using the General Linear Model Procedure (Proc GLM). The LSMEANS PDIFF option was used to compare differences between mean values at $\mathrm{p}<0.05$. Correlation coefficients were calculated using the SAS CORR procedure.

\section{RESULTS}

\section{Carcass characteristics of Korean cattle steer}

The carcass weight of Korean cattle steers was highest $(\mathrm{p}<0.05)$ in $\mathrm{QG} 1++$ and lowest in QG 1+ (Table 3). Fat thickness and slaughtering age were lowest $(p<0.05)$ in $\mathrm{QG}$ 2 , and no differences were observed among the other QGs $(1++, 1+$, and 1$) . \mathrm{LM}$ area and MS were highest $(\mathrm{p}<0.05)$ in QG 1++, and lowest in QG 2. Texture score, evaluated as 1 (fine) to 3 (coarse) by an official meat grade, was highest $(\mathrm{p}<0.05)$ in $\mathrm{QG} \mathrm{2}$, and no difference in the texture was observed among the other QGs $(1++, 1+$, and 1). Meat color, fat color, maturity, yield index, and yield grade did not differ ( $p>0.05)$ among the four QGs.

\section{Chemical composition and physicochemical traits}

Crude protein and moisture contents of loin were highest $(\mathrm{p}<0.05)$ in QG 2, and lowest in QG 1++ (Table 4). However, crude fat content of loin was highest $(p<0.05)$ in QG 1++, and lowest in QG 2. Crude protein content in the rump was also highest $(\mathrm{p}<0.05)$ in QG 2, and lowest in QG $1++$. Crude fat content in the rump was highest $(p<0.05)$ in QG $1++$. In a comparison by cut type, crude fat content was higher $(p<0.01)$ in loin than that in rump, but both crude protein and moisture contents were higher $(\mathrm{p}<0.05)$ in rump than those in loin.

Cooking loss of loin was highest $(\mathrm{p}<0.05)$ in QG 2, and no difference in cooking loss was detected among the other QGs (1++, 1+, and 1). Cooking loss of rump did not differ $(p>0.05)$ among the four QGs. Shear force of loin did not differ ( $p>0.05$ ) among the four QGs, but the numeric shear 
Table 3. Means and standard errors of slaughter age and carcass characteristics of Korean cattle steers with different quality grades examined by an official meat grader

\begin{tabular}{|c|c|c|c|c|c|c|}
\hline \multirow{2}{*}{ Item } & \multicolumn{4}{|c|}{ Korean quality grade } & \multirow{2}{*}{ SEM } & \multirow{2}{*}{$\mathrm{p}$-value } \\
\hline & $1++$ & $1+$ & 1 & 2 & & \\
\hline Slaughtering age (month) & $32.4^{\mathrm{a}}$ & $32.3^{\mathrm{a}}$ & $33.5^{\mathrm{a}}$ & $30.2^{b}$ & 0.36 & 0.01 \\
\hline Carcass weight (kg) & $441^{\mathrm{a}}$ & $397^{\mathrm{b}}$ & $429^{\mathrm{ab}}$ & $402^{\mathrm{b}}$ & 6.45 & 0.05 \\
\hline $\mathrm{LM}$ area $\left(\mathrm{cm}^{2}\right)$ & $95.2^{\mathrm{a}}$ & $83.3^{\mathrm{bc}}$ & $88.3^{b}$ & $81.2^{\mathrm{c}}$ & 1.38 & 0.01 \\
\hline Fat thickness (mm) & $14.7^{\mathrm{a}}$ & $14.6^{\mathrm{a}}$ & $15.6^{\mathrm{a}}$ & $10.4^{b}$ & 0.79 & 0.03 \\
\hline Marbling score ${ }^{1}$ & $8.42^{\mathrm{a}}$ & $6.17^{b}$ & $4.50^{\mathrm{c}}$ & $2.58^{d}$ & 0.32 & $<0.01$ \\
\hline Yield index & 64.0 & 63.6 & 62.9 & 65.8 & 0.53 & 0.09 \\
\hline Yield grade $^{2}$ & 19.2 & 18.3 & 15.8 & 21.7 & 1.06 & 0.06 \\
\hline Meat color ${ }^{3}$ & 4.50 & 4.33 & 4.42 & 4.67 & 0.07 & 0.50 \\
\hline Fat color ${ }^{4}$ & 3.00 & 3.00 & 3.00 & 3.00 & 0.00 & - \\
\hline Texture $^{5}$ & $1.00^{\mathrm{b}}$ & $1.00^{\mathrm{b}}$ & $1.00^{\mathrm{b}}$ & $2.00^{\mathrm{a}}$ & 0.06 & $<0.01$ \\
\hline Maturity $^{6}$ & 2.00 & 2.08 & 2.25 & 2.00 & 0.04 & 0.06 \\
\hline
\end{tabular}

$\mathrm{n}=12$.

SEM, standard error of the means.

${ }^{1}$ Marbling score: 1 , devoid; 9 , very abundant. ${ }^{2}$ Yield grade: A, 30; B, 20; C, 10. ${ }^{3}$ Meat color: 1, bright red; 7 , dark red.

${ }^{4}$ Fat color: 1 , white; 7 yellowish. ${ }^{5}$ Texture: 1 , very fine; 3 , very coarse. ${ }^{6}$ Maturity: 1 , youthful; 9 , mature.

${ }^{\mathrm{a}-\mathrm{d}}$ Means with different letter within a same row differ at $\mathrm{p}<0.05$.

force value was lowest in QG 1++. Shear force of rump was lowest $(\mathrm{p}<0.05)$ in $\mathrm{QG} 2$, and no difference in shear force was observed among the other QGs $(1++, 1+$, and 1). Both cooking loss and shear force were higher $(\mathrm{p}<0.01)$ in rump than those in loin.

CIE L* (lightness), a* (redness), and $b^{*}$ (yellowness) values of loin were highest $(\mathrm{p}<0.05)$ in $\mathrm{QG} 1++$, and lowest in QG 2. CIE $a^{*}$ and $b^{*}$ values in rump were highest $(p<0.05)$ in $\mathrm{QG} 1+$, whereas the $\mathrm{L}^{*}$ value did not differ $(\mathrm{p}>0.05)$ among the four QGs. All CIE values were higher $(p<0.01)$ in loin than those in rump.

\section{Sensory evaluation}

The sensory characteristics, including flavor, tenderness, juiciness, and overall acceptability did not differ among the four QGs in loin and rump (Table 5). Numeric values of tenderness, juiciness, and overall acceptability in loin were highest in QG 1++, and those of juiciness and overall acceptability were lowest in QG 2. All sensory characteristics were higher $(\mathrm{p}<0.05)$ in loin than those in rump.

\section{Nucleotide content}

AMP and IMP contents were not different among the four QGs in loin and rump (Table 6). Inosine contents of loin and rump were not different among the QGs. Hypoxanthine content of loin was highest $(\mathrm{p}<0.05)$ in QG 1 , and lowest in QG 1++. Similarly, hypoxanthine content of rump was highest $(\mathrm{p}<0.05)$ in QG 2, but did not differ among the other three QGs $(1++, 1+$, and 1). IMP content was higher $(p<0.01)$ in rump than that in loin, whereas hypoxanthine content was higher $(\mathrm{p}<0.05)$ in loin than that in rump.

\section{Collagen contents}

Total, soluble, and insoluble collagen contents of loin

Table 4. $\mathrm{pH}$, chemical composition, cooking loss, meat color (CIE L*, $\mathrm{a}^{*}$, and $\mathrm{b}^{*}$ ), and Warner-Bratzler shear force of loin and rump with different quality grades in Korean cattle steers

\begin{tabular}{|c|c|c|c|c|c|c|c|c|c|c|c|c|c|}
\hline \multirow{2}{*}{ Item } & \multicolumn{4}{|c|}{ Loin } & \multicolumn{6}{|c|}{ Rump } & \multicolumn{2}{|c|}{ Cut } & \multirow{2}{*}{ p-value } \\
\hline & $1++$ & $1+$ & 1 & 2 & SEM & $1++$ & $1+$ & 1 & 2 & SEM & Loin & Rump & \\
\hline$\overline{\mathrm{pH}}$ & $5.47^{\mathrm{b}}$ & $5.48^{\mathrm{b}}$ & $5.51^{\mathrm{ab}}$ & $5.55^{\mathrm{a}}$ & 0.01 & 5.50 & 5.51 & 5.51 & 5.49 & 0.01 & 5.50 & 5.50 & 0.82 \\
\hline Protein (\%) & $17.9^{\mathrm{c}}$ & $19.7^{\mathrm{b}}$ & $20.8^{\mathrm{a}}$ & $21.3^{\mathrm{a}}$ & 0.25 & $21.4^{\mathrm{b}}$ & $21.5^{\mathrm{b}}$ & $22.9^{\mathrm{a}}$ & $23.0^{\mathrm{a}}$ & 0.16 & 19.9 & 22.2 & 0.02 \\
\hline Fat $(\%)$ & $23.8^{\mathrm{a}}$ & $17.3^{\mathrm{b}}$ & $14.1^{\mathrm{bc}}$ & $9.90^{\mathrm{c}}$ & 1.00 & $6.20^{\mathrm{a}}$ & $4.09^{\mathrm{ab}}$ & $2.78^{\mathrm{b}}$ & $3.60^{\mathrm{b}}$ & 0.41 & 16.3 & 4.17 & $<0.01$ \\
\hline Moisture (\%) & $55.6^{\mathrm{c}}$ & $60.6^{\mathrm{b}}$ & $63.6^{\mathrm{b}}$ & $67.1^{\mathrm{a}}$ & 0.81 & 70.2 & 71.4 & 72.1 & 71.1 & 0.30 & 61.7 & 71.2 & $<0.01$ \\
\hline Cooking loss (\%) & $25.5^{\mathrm{b}}$ & $27.5^{\mathrm{b}}$ & $26.9^{b}$ & $34.5^{\mathrm{a}}$ & 1.17 & 34.4 & 34.2 & 34.2 & 32.8 & 0.45 & 28.6 & 33.9 & $<0.01$ \\
\hline Shear force $(\mathrm{kg})$ & 3.83 & 4.79 & 5.39 & 5.23 & 0.26 & $13.7^{\mathrm{a}}$ & $14.0^{\mathrm{a}}$ & $15.1^{\mathrm{a}}$ & $9.30^{\mathrm{b}}$ & 0.65 & 4.81 & 13.02 & $<0.01$ \\
\hline CIE L* & $43.6^{\mathrm{a}}$ & $41.4^{\mathrm{b}}$ & $40.4^{\mathrm{b}}$ & $40.1^{\mathrm{b}}$ & 0.32 & 39.6 & 39.6 & 38.9 & 39.3 & 0.15 & 41.4 & 39.4 & $<0.01$ \\
\hline CIE a* & $16.0^{\mathrm{a}}$ & $15.6^{\mathrm{a}}$ & $14.5^{\mathrm{ab}}$ & $13.8^{\mathrm{b}}$ & 0.31 & $11.6^{\mathrm{ab}}$ & $12.2^{\mathrm{a}}$ & $10.9^{b}$ & $10.8^{\mathrm{b}}$ & 0.18 & 15.0 & 11.4 & $<0.01$ \\
\hline CIE b* & $4.68^{\mathrm{a}}$ & $4.09^{\mathrm{a}}$ & $3.15^{\mathrm{b}}$ & $2.61^{\mathrm{b}}$ & 0.18 & $1.24^{\mathrm{a}}$ & $1.47^{\mathrm{a}}$ & $0.65^{\mathrm{b}}$ & $1.34^{\mathrm{a}}$ & 0.09 & 3.63 & 1.17 & $<0.01$ \\
\hline
\end{tabular}

$\mathrm{n}=12$.

CIE, International Commission on Illumination; SEM, standard error of the means.

${ }^{\mathrm{a}-\mathrm{c}}$ Means with different letter within a same row differ at $\mathrm{p}<0.05$. 
Table 5. Sensory characteristics of loin and rump with different quality grades in Korean cattle steers

\begin{tabular}{|c|c|c|c|c|c|c|c|c|c|c|c|c|c|}
\hline \multirow{2}{*}{ Item $^{1}$} & \multicolumn{4}{|c|}{ Loin } & \multicolumn{6}{|c|}{ Rump } & \multicolumn{2}{|c|}{ Cut } & \multirow{2}{*}{ p-value } \\
\hline & $1++$ & $1+$ & 1 & 2 & SEM & $1++$ & $1+$ & 1 & 2 & SEM & Loin & Rump & \\
\hline Appearance & 6.45 & 6.45 & 6.38 & 6.37 & 0.07 & 6.17 & 5.70 & 4.85 & 5.00 & 0.26 & 6.41 & 5.43 & 0.01 \\
\hline Odor & 6.00 & 5.95 & 6.30 & 5.70 & 0.19 & 4.80 & 4.45 & 4.30 & 3.90 & 0.21 & 5.99 & 4.36 & 0.04 \\
\hline Taste & 6.55 & 6.30 & 6.67 & 5.95 & 0.18 & 4.10 & 3.95 & 4.15 & 3.50 & 0.24 & 6.37 & 3.93 & 0.02 \\
\hline Flavor & 6.35 & 6.05 & 6.45 & 6.00 & 0.16 & 4.00 & 3.79 & 4.10 & 3.17 & 0.25 & 6.21 & 3.77 & 0.02 \\
\hline Tenderness & 7.20 & 5.95 & 6.65 & 6.25 & 0.27 & 3.60 & 3.13 & 3.85 & 2.95 & 0.33 & 6.51 & 3.38 & 0.02 \\
\hline Juiciness & 6.70 & 5.70 & 5.95 & 5.55 & 0.24 & 3.50 & 3.45 & 3.60 & 2.85 & 0.26 & 5.98 & 3.35 & 0.01 \\
\hline Overall acceptability & 6.95 & 6.30 & 6.50 & 5.95 & 0.23 & 3.65 & 3.55 & 3.95 & 3.15 & 0.23 & 6.43 & 3.58 & 0.01 \\
\hline
\end{tabular}

$\mathrm{n}=3$.

SEM, standard error of the means.

${ }^{1}$ The score was evaluated with 10 semi-trained panelists (1, extremely dislike; 5 , neither dislike nor like; 9 , extremely like).

Table 6. Nucleotides contents $(\mathrm{mg} / 100 \mathrm{~g})$ of loin and rump with different quality grades in Korean cattle steers

\begin{tabular}{|c|c|c|c|c|c|c|c|c|c|c|c|c|c|}
\hline \multirow{2}{*}{ Nucleotide } & \multicolumn{4}{|c|}{ Loin } & & \multicolumn{5}{|c|}{ Rump } & \multicolumn{2}{|c|}{ Cut } & \multirow{2}{*}{$\mathrm{p}$-value } \\
\hline & $1++$ & $1+$ & 1 & 2 & SEM & $1++$ & $1+$ & 1 & 2 & SEM & Loin & Rump & \\
\hline AMP & 2.86 & 2.68 & 3.05 & 3.05 & 0.08 & 2.37 & 2.35 & 2.05 & 2.75 & 0.11 & 2.91 & 2.38 & $<0.01$ \\
\hline IMP & 120 & 135 & 116 & 104 & 6.50 & 196 & 184 & 189 & 173 & 5.16 & 119 & 186 & $<0.01$ \\
\hline Inosine & $65.7^{\mathrm{b}}$ & $77.0^{\mathrm{a}}$ & $80.2^{\mathrm{a}}$ & $78.3^{\mathrm{a}}$ & 1.18 & $66.8^{\mathrm{b}}$ & $74.5^{\mathrm{b}}$ & $67.6^{\mathrm{b}}$ & $88.9^{\mathrm{a}}$ & 1.92 & 75.3 & 74.5 & 0.66 \\
\hline Hypoxanthine & $2.62^{\mathrm{c}}$ & $4.82^{\mathrm{bc}}$ & $8.48^{\mathrm{a}}$ & $8.10^{\mathrm{ab}}$ & 0.79 & $2.24^{\mathrm{b}}$ & $3.57^{\mathrm{b}}$ & $1.95^{\mathrm{b}}$ & $6.27^{\mathrm{a}}$ & 0.42 & 6.00 & 3.51 & 0.03 \\
\hline
\end{tabular}

$\mathrm{n}=12$.

SEM, standard error of the means; AMP, adenosine mono-phosphate; IMP, inosine mono-phosphate.

${ }^{\mathrm{a}-\mathrm{c}}$ Means with different letter within a same row differ at $\mathrm{p}<0.05$.

were highest $(\mathrm{p}<0.05)$ in QG $1++$, and lowest in QG 1 (Table 7). All three types of collagen in rump were highest $(p<0.05)$ in QG $1+$, and lowest in QG 1. All three types of collagen were higher $(\mathrm{p}<0.01)$ in rump than those in loin.

\section{Free amino acid contents}

Isoleucine, leucine, and tyrosine contents of loin were highest $(\mathrm{p}<0.05)$ in QG $1++$, and lowest in QG 2 (Table 8). However, those of rump were highest $(\mathrm{p}<0.05)$ in $\mathrm{QG} 2$ than those in the other QGs. Methionine, phenylalanine, and valine contents of loin did not differ among the four QGs. However, those of rump were highest $(p<0.05)$ in QG 2 . Alanine, arginine, cysteine, glutamic acid, lysine, serine, and threonine contents did not differ among the four QGs in loin and rump. Glutamic acid, isoleucine, leucine, lysine, serine, tyrosine, and valine contents were higher $(p<0.05)$ in loin than those in rump, whereas arginine, cysteine, glycine, histidine, and threonine contents were higher $(p<0.05)$ in rump than those in loin.

\section{Correlation analyses}

Results of correlation analyses were presented in Tables 9 to 12 . Briefly, MS was positively correlated with QG ( $\mathrm{r}=$ $0.98 ; \mathrm{p}<0.001)$, crude fat content $(\mathrm{r}=0.76 ; \mathrm{p}<0.001)$, juiciness $(\mathrm{r}=0.82 ; \mathrm{p}<0.01)$, and overall acceptability $(\mathrm{r}=$ $0.88 ; \mathrm{p}<0.001)$; however, MS was negatively correlated with texture $(\mathrm{r}=-0.75 ; \mathrm{p}<0.001)$, moisture content $(\mathrm{r}=$ $-0.77 ; \mathrm{p}<0.001)$, and crude protein content $(\mathrm{r}=-0.80$; $\mathrm{p}<0.001)$. QG was positively correlated with crude fat content $(\mathrm{r}=0.73 ; \mathrm{p}<0.001)$, juiciness $(\mathrm{r}=0.81 ; \mathrm{p}<0.01)$, and overall acceptability $(\mathrm{r}=0.87 ; \mathrm{p}<0.001)$; however, it was negatively correlated with texture $(\mathrm{r}=-0.78 ; \mathrm{p}<0.001)$, moisture content $(\mathrm{r}=-0.75 ; \mathrm{p}<0.001)$, and crude protein content $(\mathrm{r}=-0.75 ; \mathrm{p}<0.001)$. Tenderness was positively correlated with juiciness $(\mathrm{r}=0.92 ; \mathrm{p}<0.001)$, flavor $(\mathrm{r}=$ $0.77 ; \mathrm{p}<0.01)$, and overall acceptability $(\mathrm{r}=0.84 ; \mathrm{p}<0.01)$. Tenderness was positively correlated with total collagen $(\mathrm{r}=$ $0.75 ; \mathrm{p}<0.01)$, soluble collagen $(\mathrm{r}=0.61 ; \mathrm{p}<0.05)$, and insoluble collagen contents $(\mathrm{r}=0.72 ; \mathrm{p}<0.01)$. Overall

Table 7. Collagen contents $(\mathrm{mg} / \mathrm{g})$ of loin and rump with different quality grades in Korean cattle steers

\begin{tabular}{|c|c|c|c|c|c|c|c|c|c|c|c|c|c|}
\hline \multirow{2}{*}{ Collagen } & \multicolumn{4}{|c|}{ Loin } & \multicolumn{6}{|c|}{ Rump } & \multicolumn{2}{|c|}{ Cut } & \multirow{2}{*}{ p-value } \\
\hline & $1++$ & $1+$ & 1 & 2 & SEM & $1++$ & $1+$ & 1 & 2 & SEM & Loin & Rump & \\
\hline Total collagen & $5.93^{\mathrm{a}}$ & $4.76^{\mathrm{bc}}$ & $3.90^{\mathrm{c}}$ & $5.04^{\mathrm{ab}}$ & 0.18 & $9.23^{\mathrm{a}}$ & $10.29^{\mathrm{a}}$ & $5.12^{\mathrm{c}}$ & $7.37^{b}$ & 0.40 & 4.91 & 8.01 & $<0.01$ \\
\hline Soluble collagen & $2.45^{\mathrm{a}}$ & $2.06^{\mathrm{b}}$ & $1.64^{\mathrm{c}}$ & $2.13^{\mathrm{ab}}$ & 0.08 & $3.73^{\mathrm{b}}$ & $4.55^{\mathrm{a}}$ & $2.15^{\mathrm{d}}$ & $2.96^{\mathrm{c}}$ & 0.19 & 2.07 & 3.35 & $<0.01$ \\
\hline Insoluble collagen & $3.48^{\mathrm{a}}$ & $2.70^{\mathrm{bc}}$ & $2.26^{\mathrm{c}}$ & $2.91^{\mathrm{ab}}$ & 0.12 & $5.50^{\mathrm{a}}$ & $5.75^{\mathrm{a}}$ & $2.97^{\mathrm{c}}$ & $4.41^{\mathrm{b}}$ & 0.23 & 2.84 & 4.66 & $<0.01$ \\
\hline
\end{tabular}

$\mathrm{n}=12$.

SEM, standard error of the means.

${ }^{\mathrm{a}-\mathrm{d}}$ Means with different letter within a same row differ at $\mathrm{p}<0.05$. 
Table 8. The concentration $(\mathrm{mg} / 100 \mathrm{~g})$ of free amino acid of loin and rump with different quality grades in Korean cattle steers

\begin{tabular}{|c|c|c|c|c|c|c|c|c|c|c|c|c|c|}
\hline \multirow{2}{*}{ Amino acid } & \multicolumn{4}{|c|}{ Loin } & \multicolumn{6}{|c|}{ Rump } & \multicolumn{2}{|c|}{ Cut } & \multirow{2}{*}{ p-value } \\
\hline & $1++$ & $1+$ & 1 & 2 & SEM & $1++$ & $1+$ & 1 & 2 & SEM & Loin & Rump & \\
\hline Alanine & 14.7 & 14.4 & 14.1 & 15.9 & 0.36 & 15.6 & 15.4 & 16.1 & 14.7 & 0.32 & 14.8 & 15.5 & 0.21 \\
\hline Arginine & 93.9 & 96.9 & 102 & 107 & 4.20 & 126 & 134 & 139 & 130 & 2.57 & 100 & 132 & $<0.01$ \\
\hline Cysteine & 3.04 & 2.46 & 2.50 & 2.75 & 0.10 & 3.15 & 2.96 & 2.80 & 2.96 & 0.09 & 2.68 & 2.97 & 0.04 \\
\hline Glutamic acid & 7.20 & 6.47 & 6.91 & 7.10 & 0.26 & 5.11 & 5.49 & 5.70 & 6.13 & 0.15 & 6.92 & 5.61 & $<0.01$ \\
\hline Glycine & 4.83 & 4.73 & 5.03 & 5.32 & 0.08 & $5.13^{\mathrm{b}}$ & $5.34^{\mathrm{ab}}$ & $5.82^{\mathrm{a}}$ & $5.44^{\mathrm{ab}}$ & 0.09 & 4.98 & 5.43 & 0.01 \\
\hline Histidine & $18.4^{\mathrm{b}}$ & $18.5^{\mathrm{b}}$ & $19.9^{\mathrm{b}}$ & $31.8^{\mathrm{a}}$ & 1.42 & 26.4 & 27.8 & 31.6 & 24.9 & 0.92 & 22.13 & 27.70 & 0.01 \\
\hline Isoleucine & $5.92^{\mathrm{a}}$ & $5.58^{\mathrm{ab}}$ & $5.70^{\mathrm{ab}}$ & $5.38^{\mathrm{b}}$ & 0.07 & $4.97^{\mathrm{c}}$ & $4.99^{\mathrm{c}}$ & $5.33^{\mathrm{b}}$ & $5.74^{\mathrm{a}}$ & 0.07 & 5.65 & 5.26 & 0.01 \\
\hline Leucine & $9.43^{\mathrm{a}}$ & $8.48^{\mathrm{bc}}$ & $8.91^{\mathrm{ab}}$ & $8.02^{\mathrm{c}}$ & 0.14 & $7.17^{\mathrm{bc}}$ & $6.63^{\mathrm{c}}$ & $7.86^{\mathrm{ab}}$ & $8.71^{\mathrm{a}}$ & 0.22 & 8.71 & 7.59 & 0.02 \\
\hline Lysine & 9.20 & 8.13 & 8.44 & 8.09 & 0.20 & 6.02 & 5.70 & 6.74 & 7.28 & 0.33 & 8.46 & 6.43 & $<0.01$ \\
\hline Methionine & 6.23 & 5.96 & 6.11 & 5.91 & 0.05 & $5.57^{\mathrm{b}}$ & $5.67^{\mathrm{b}}$ & $5.89^{\mathrm{b}}$ & $6.39^{\mathrm{a}}$ & 0.07 & 6.05 & 5.88 & 0.09 \\
\hline Phenylalanine & 7.67 & 6.97 & 6.91 & 6.84 & 0.17 & $6.39^{c}$ & $6.42^{\mathrm{c}}$ & $6.89^{\mathrm{b}}$ & $7.42^{\mathrm{a}}$ & 0.10 & 7.10 & 6.78 & 0.15 \\
\hline Proline & $3.91^{\mathrm{a}}$ & $3.74^{\mathrm{ab}}$ & $3.67^{\mathrm{b}}$ & $3.87^{\mathrm{a}}$ & 0.03 & 3.69 & 3.65 & 3.82 & 3.80 & 0.03 & 3.80 & 3.74 & 0.17 \\
\hline Serine & 7.27 & 6.95 & 7.13 & 7.15 & 0.12 & 5.79 & 6.31 & 6.80 & 6.97 & 0.18 & 7.13 & 6.47 & 0.02 \\
\hline Threonine & 21.2 & 20.8 & 23.1 & 19.3 & 1.07 & 25.7 & 25.3 & 25.9 & 30.1 & 1.08 & 21.1 & 26.7 & 0.02 \\
\hline Tyrosine & $8.24^{\mathrm{a}}$ & $7.70^{\mathrm{ab}}$ & $8.19^{\mathrm{a}}$ & $7.00^{\mathrm{b}}$ & 0.14 & $6.55^{\mathrm{b}}$ & $6.65^{\mathrm{b}}$ & $6.97^{\mathrm{b}}$ & $7.89^{\mathrm{a}}$ & 0.12 & 7.78 & 7.02 & 0.01 \\
\hline Valine & 7.04 & 6.48 & 6.72 & 6.33 & 0.10 & $5.40^{\mathrm{b}}$ & $5.47^{\mathrm{b}}$ & $5.83^{\mathrm{b}}$ & $6.56^{\mathrm{a}}$ & 0.11 & 6.64 & 5.81 & $<0.01$ \\
\hline
\end{tabular}

$\mathrm{n}=12$.

SEM, standard error of the means.

${ }^{\mathrm{a}-\mathrm{c}}$ Means with different letter within a same row differ at $\mathrm{p}<0.05$.

acceptability was also positively correlated with total collagen $(r=0.70 ; p<0.05)$, soluble collagen $(r=0.65$; $\mathrm{p}<0.05)$, and insoluble collagen contents $(\mathrm{r}=0.63 ; \mathrm{p}<0.05)$.

Tenderness was positively correlated with glutamic acid $(\mathrm{r}=0.72 ; \mathrm{p}<0.01)$, leucine $(\mathrm{r}=0.77 ; \mathrm{p}<0.01)$, lysine $(\mathrm{r}=$ $0.75 ; \mathrm{p}<0.01)$, proline $(\mathrm{r}=0.72 ; \mathrm{p}<0.01)$, tyrosine $(\mathrm{r}=0.70$; $\mathrm{p}<0.05)$, and valine contents $(\mathrm{r}=0.72 ; \mathrm{p}<0.01)$. Juiciness was positively correlated with glutamic acid $(\mathrm{r}=0.68$; $\mathrm{p}<0.05)$ and proline contents $(\mathrm{r}=0.82 ; \mathrm{p}<0.01)$. Flavor was positively correlated with isoleucine $(\mathrm{r}=0.70 ; \mathrm{p}<0.05)$, leucine $(r=0.75 ; p<0.01)$, and lysine $(r=0.82 ; p<0.01)$. Overall acceptability was positively correlated with glutamic acid $(r=0.60 ; \mathrm{p}<0.05)$ and proline contents $(\mathrm{r}=$ $0.78 ; \mathrm{p}<0.01)$.

\section{DISCUSSION}

This study was performed to compare carcass traits, sensory characteristics, chemical compositions, nucleotide contents, collagen contents, and free amino acid contents among QGs to understand association between MS/QG and these parameters in loin and rump of Korean cattle steers.

Our results indicate that MS were higher with better QG, whereas texture score was lower with better QG 2. These results agree with those of Cho et al. (2010), who reported that carcass weight was highest in QG 1++ and texture was highest in QG 2 in Korean cattle steers. Moon et al. (2003) also found that carcass weight and LM area increased with increasing QG; however, texture decreased with increasing QG. Overall, beef with the best QG revealed the highest

Table 9. Pearson correlation coefficients between carcass traits and physico-chemical characteristics of loin in Korean cattle steers

\begin{tabular}{lcccccccccc}
\hline Item & $\begin{array}{c}\text { Carcass } \\
\text { weight }\end{array}$ & LM area & $\begin{array}{c}\text { Fat } \\
\text { thickness }\end{array}$ & Marbling & $\begin{array}{c}\text { Quality } \\
\text { grade }\end{array}$ & $\begin{array}{c}\text { Yield } \\
\text { grade }\end{array}$ & $\begin{array}{c}\text { Yield } \\
\text { index }\end{array}$ & Meat color & Texture & Maturity \\
\hline Slaughtering age & $0.41^{* *}$ & $0.36^{*}$ & 0.12 & 0.18 & 0.24 & 0.02 & -0.10 & $-0.31^{*}$ & $-0.44^{* *}$ & 0.11 \\
Carcass weight & - & $0.61^{* * *}$ & $0.34^{*}$ & 0.21 & 0.22 & -0.27 & $-0.39^{* *}$ & -0.25 & -0.20 & 0.14 \\
LM area & & - & 0.16 & $0.46^{* *}$ & $0.44^{* *}$ & 0.17 & 0.01 & 0.03 & $-0.35^{*}$ & 0.13 \\
Fat thickness & & & - & 0.23 & 0.24 & $-0.80^{* * *}$ & $-0.96^{* * *}$ & -0.11 & $-0.36^{*}$ & -0.05 \\
Marbling & & & & - & $0.98^{* * *}$ & -0.07 & -0.12 & -0.09 & $-0.75^{* * *}$ & -0.06 \\
Quality grade & & & & & - & -0.08 & -0.14 & -0.13 & $-0.78^{* * *}$ & -0.07 \\
Yield grade & & & & & & - & $0.86^{* * *}$ & 0.17 & 0.23 & -0.05 \\
Yield index & & & & & & & - & 0.18 & 0.27 & 0.05 \\
Meat color & & & & & & & & - & 0.22 & 0.01 \\
Texture & & & & & & & & -0.17 & - \\
\hline
\end{tabular}

LM, longissimus muscle.

$* \mathrm{p}<0.05 ; * * \mathrm{p}<0.01 ; * * * \mathrm{p}<0.001$. 
Table 10. Pearson correlation coefficients among carcass traits and physico-chemical and sensory characteristics of loin in Korean cattle steers

\begin{tabular}{|c|c|c|c|c|c|c|c|c|c|c|c|c|c|}
\hline Item & Moisture & Protein & Fat & $\begin{array}{c}\text { Cooking } \\
\text { loss }\end{array}$ & Shear force & $\mathrm{pH}$ & $\mathrm{L}^{*}$ & $a^{*}$ & $\mathrm{~b}^{*}$ & Tenderness & Juiciness & Flavor & $\begin{array}{c}\text { Overall } \\
\text { acceptability }\end{array}$ \\
\hline Slaughtering age & -0.19 & -0.15 & 0.14 & -0.09 & -0.06 & 0.04 & 0.14 & 0.03 & 0.14 & 0.36 & 0.45 & 0.43 & 0.52 \\
\hline Carcass weight & -0.14 & -0.12 & 0.11 & -0.18 & -0.01 & 0.27 & 0.21 & $0.36^{*}$ & $0.33^{*}$ & 0.46 & 0.51 & 0.38 & 0.52 \\
\hline LM area & $-0.43^{* *}$ & $-0.42^{* *}$ & $0.41 * *$ & -0.21 & -0.20 & -0.09 & 0.22 & 0.23 & 0.25 & $0.66^{*}$ & $0.75 * *$ & 0.53 & $0.74 * *$ \\
\hline Fat thickness & -0.07 & -0.01 & 0.07 & -0.13 & 0.14 & 0.19 & 0.14 & 0.26 & $0.35^{*}$ & 0.05 & 0.32 & 0.02 & 0.40 \\
\hline Marbling & $-0.77 * * *$ & $-0.80 * * *$ & $0.76^{* * *}$ & $-0.32 *$ & $-0.33^{*}$ & $-0.37 *$ & $0.59^{* * *}$ & $0.46^{* * *}$ & $0.68 * * *$ & 0.55 & $0.82 * *$ & 0.43 & $0.88^{* * *}$ \\
\hline Quality grade & $-0.75^{* * *}$ & $-0.75 * * *$ & $0.73 * * *$ & $-0.37 *$ & $-0.30^{*}$ & $-0.39 * *$ & $0.57 * * *$ & $0.41 * *$ & $0.66^{* * *}$ & 0.51 & $0.81 * *$ & 0.38 & $0.87 * * *$ \\
\hline Yield grade & -0.01 & -0.07 & -0.001 & 0.20 & -0.14 & $-0.36^{*}$ & -0.12 & -0.22 & $-0.33^{*}$ & 0.26 & 0.10 & 0.37 & 0.10 \\
\hline Yield index & -0.04 & -0.10 & 0.04 & 0.10 & -0.19 & -0.28 & -0.12 & -0.26 & $-0.33^{*}$ & 0.14 & -0.09 & 0.13 & -0.16 \\
\hline Meat color & 0.21 & 0.03 & -0.13 & 0.24 & 0.03 & -0.04 & -0.11 & -0.27 & $-0.30^{*}$ & -0.20 & -0.11 & -0.14 & -0.06 \\
\hline Texture & $0.55^{* * *}$ & $0.47 * *$ & $-0.53 * * *$ & $0.42 * *$ & 0.14 & $0.35^{*}$ & $-0.32 *$ & $-0.32 *$ & $-0.49 * * *$ & -0.32 & -0.56 & $-0.64 *$ & $-0.76^{* *}$ \\
\hline Maturity & 0.09 & 0.08 & -0.06 & 0.07 & 0.01 & 0.09 & -0.07 & 0.02 & -0.04 & -0.20 & -0.15 & 0.09 & -0.03 \\
\hline Moisture & - & $0.91 * * *$ & $-0.98 * * *$ & $0.41 * *$ & $0.29 *$ & $0.33^{*}$ & $-0.57 * * *$ & $-0.44 * *$ & $-0.62 * * *$ & $-0.62 *$ & $-0.77 * *$ & -0.29 & $-0.71 * *$ \\
\hline Protein & & - & $-0.93 * * *$ & 0.26 & $0.36^{*}$ & 0.20 & $-0.67 * * *$ & $-0.44 * *$ & $-0.63 * * *$ & -0.55 & $-0.77 * *$ & -0.32 & $-0.76^{* *}$ \\
\hline Fat & & & - & $-0.41 * *$ & $-0.30^{*}$ & $-0.31^{*}$ & $0.59 * * *$ & $0.41 * *$ & $0.60 * * *$ & 0.56 & $0.73 * *$ & 0.30 & $0.70^{*}$ \\
\hline Cooking loss & & & & - & 0.13 & 0.15 & -0.15 & -0.06 & -0.23 & -0.52 & $-0.69^{*}$ & -0.28 & $-0.67^{*}$ \\
\hline Shear force & & & & & - & -0.05 & $-0.35^{*}$ & -0.25 & -0.27 & -0.32 & -0.54 & -0.19 & -0.58 \\
\hline $\mathrm{pH}$ & & & & & & - & 0.06 & 0.02 & -0.07 & -0.29 & -0.14 & -0.42 & -0.15 \\
\hline $\mathrm{L}^{*}$ & & & & & & & - & $0.41 * *$ & $0.67 * * *$ & 0.36 & 0.51 & 0.20 & 0.51 \\
\hline$a^{*}$ & & & & & & & & - & $0.76^{* * *}$ & 0.28 & 0.51 & 0.16 & 0.54 \\
\hline $\mathrm{b}^{*}$ & & & & & & & & & - & 0.04 & 0.30 & -0.03 & 0.36 \\
\hline Tenderness & & & & & & & & & & - & $0.92 * * *$ & $0.77 * *$ & $0.84 * *$ \\
\hline Juiciness & & & & & & & & & & & - & $0.68^{*}$ & $0.96^{* * *}$ \\
\hline Flavor & & & & & & & & & & & & - & $0.76^{* *}$ \\
\hline
\end{tabular}

LM, longissimus muscle. ${ }^{*} \mathrm{p}<0.05 ;{ }^{* *} \mathrm{p}<0.01 ; * * * \mathrm{p}<0.001$.

MS but the lowest texture. MS was strongly correlated $(\mathrm{r}=$ 0.98 ) with QG, whereas texture was negatively correlated ( $\mathrm{r}$ $=-0.78$ ) with QG. Similar strong MS with QG correlations have been reported previously (Dow et al., 2011). In Korean cattle, beef with higher MS revealed better QG (Lee et al., 2012). QG.

Our results confirm that MS is a major determinant of

Fat content in loin was highest in $\mathrm{QG} 1++$, whereas protein and moisture contents were lowest in QG $1++$. Other studies have also reported an inverse relationship between moisture content and crude fat content in bovine muscle (Cho et al., 2010; Legako et al., 2015). Fat content was markedly higher in loin than that in rump, whereas protein content was lower in loin than that in rump. Cho et al. (2008) also showed that fat content was highest but protein content was lowest in loin among other cuts, including the short plate, top sirloin, striploin, chunk tender, eye of round, chunk roll, bottom round, rump, and brisket in Korean cattle steers. Our correlation analysis revealed that fat content in loin was strongly correlated $(r=0.73)$ with QG. Our results confirm that intramuscular fat (IMF) content is a major contributor to QG.

Meat color is important when selecting fresh meat at the market. The CIE L*, $a^{*}$, and $b^{*}$ values in loin were highest in QG $1++$, which is consistent with a study reporting the highest $\mathrm{L}^{*}, \mathrm{a}^{*}$, and $\mathrm{b}^{*}$ values in QG $1++$, among all QGs in Korean cattle steers (Lim et al., 2014). The L*, $\mathrm{a}^{*}$, and $\mathrm{b}^{*}$ values were higher in loin than those in rump. Previous study also reported that the $\mathrm{L}^{*}$ value is higher in loin than that in rump from Korean cattle (Cho et al., 2013). Our correlation analysis revealed that the $\mathrm{L}^{*}, \mathrm{a}^{*}$, and $\mathrm{b}^{*}$ values were correlated with QG, MS, and fat content in loin. Therefore, higher $\mathrm{L}^{*}, \mathrm{a}^{*}$, and $\mathrm{b}^{*}$ values in a good QG loin may reflect higher fat content. Sarriés and Beriain (2006) reported that IMF contributes the increase in $b^{*}$-value leading to increasing $\mathrm{L}^{*}$-value in a positive relationship. A similar association between meat color values and IMF content has been reported (Jo et al., 2013).

Cooking loss in loin was significantly higher in QG 2 than that in the other QGs $(1++, 1+$, and 1). This result agrees with previous study showing greater cooking loss in lower QG loin from Korean cattle (Moon et al., 2006). Ozawa et al. (2000) reported that cooking loss of longissimus thoracis with a high MS was significantly lower than that with a low MS in Japanese black steers (Wagyu). In this study, cooking loss was significantly lower in loin than that in rump. Another study also reported that cooking loss is significantly lower in loin than that in several other cuts of Korean cattle (Cho et al., 2013). Our correlation analysis revealed that cooking loss was negatively correlated with loin fat content. Therefore, our results suggest that greater cooking loss with lower QG is due, in part, to lower fat content.

Shear force values tended to be lowest in QG $1++$, but the difference was not significant. Shear force was 
Table 11. Pearson correlation coefficient between carcass traits and chemical composition, and sensory characteristics and collagen and nucleotide contents of loin in Korean cattle steers

\begin{tabular}{|c|c|c|c|c|c|c|c|}
\hline Item & Total collagen & $\begin{array}{c}\text { Soluble } \\
\text { collagen }\end{array}$ & $\begin{array}{l}\text { Insoluble } \\
\text { collagen }\end{array}$ & AMP & IMP & Inosine & Hypoxanthine \\
\hline Slaughtering age & 0.03 & 0.03 & 0.03 & 0.19 & -0.17 & 0.16 & 0.18 \\
\hline Carcass weight & 0.08 & 0.07 & 0.08 & 0.13 & -0.23 & -0.26 & 0.21 \\
\hline LM area & 0.09 & 0.09 & 0.08 & -0.03 & -0.08 & $-0.35^{*}$ & 0.001 \\
\hline Fat thickness & -0.03 & 0.01 & -0.05 & -0.04 & -0.13 & 0.02 & 0.18 \\
\hline Marbling & $0.30^{*}$ & 0.27 & $0.29 *$ & -0.21 & 0.17 & $-0.58 * * *$ & $-0.43 * *$ \\
\hline Quality grade & $0.32 *$ & $0.29 *$ & $0.31 *$ & -0.19 & 0.17 & $-0.57 * * *$ & $-0.42 * *$ \\
\hline Yield grade & 0.13 & 0.12 & 0.12 & 0 & 0.25 & 0.02 & $-0.29 *$ \\
\hline Yield index & 0.03 & 0.003 & 0.04 & -0.02 & 0.16 & -0.06 & -0.22 \\
\hline Meat color & -0.23 & -0.15 & -0.26 & 0.16 & 0.06 & -0.06 & 0.03 \\
\hline Texture & 0.06 & 0.07 & 0.05 & 0.15 & -0.19 & 0.22 & 0.23 \\
\hline Maturity & -0.16 & -0.12 & -0.17 & -0.10 & -0.18 & -0.02 & $0.29 *$ \\
\hline Moisture & -0.14 & -0.13 & -0.14 & 0.11 & -0.06 & $0.51 * * *$ & $0.45 * *$ \\
\hline Protein & -0.27 & -0.24 & -0.27 & 0.19 & -0.003 & $0.63 * * *$ & $0.41^{* *}$ \\
\hline Fat & 0.14 & 0.10 & 0.15 & -0.14 & 0.07 & $-0.54 * * *$ & $-0.45^{* *}$ \\
\hline Cooking loss & -0.01 & 0.03 & -0.03 & 0.14 & -0.08 & $0.35^{*}$ & 0.19 \\
\hline Shear force & -0.23 & -0.24 & -0.20 & 0.20 & 0.22 & 0.26 & -0.04 \\
\hline $\mathrm{pH}$ & 0.05 & 0.01 & 0.06 & 0.01 & $-0.61 * * *$ & 0.09 & $0.68 * * *$ \\
\hline $\mathrm{L}^{*}$ & $0.29 *$ & 0.17 & $0.35^{*}$ & -0.17 & -0.17 & $-0.43 * *$ & -0.15 \\
\hline$a^{*}$ & 0.09 & 0.08 & 0.09 & -0.10 & -0.09 & $-0.29 *$ & -0.10 \\
\hline$b^{*}$ & 0.18 & 0.09 & 0.21 & -0.20 & -0.05 & $-0.41 * *$ & -0.22 \\
\hline Tenderness & $0.75^{* *}$ & $0.61^{*}$ & $0.72 * *$ & 0.13 & -0.32 & -0.28 & -0.31 \\
\hline Juiciness & $0.79 * *$ & $0.75^{* *}$ & $0.69^{*}$ & 0.06 & -0.55 & -0.53 & -0.12 \\
\hline Flavor & 0.43 & 0.18 & 0.53 & 0.14 & 0.07 & 0.07 & -0.18 \\
\hline Overall acceptability & $0.70^{*}$ & $0.65^{*}$ & $0.63 *$ & 0.05 & -0.49 & -0.48 & -0.02 \\
\hline
\end{tabular}

AMP, adenosine mono-phosphate; IMP, inosine mono-phosphate; LM, longissimus muscle.

$* \mathrm{p}<0.05 ; * * \mathrm{p}<0.01 ; * * * \mathrm{p}<0.001$.

markedly lower in loin than that in rump. Several studies have reported that shear force in Korean cattle is lower in loin with a better QG (Moon et al., 2006; Lim et al., 2014).

Numeric values of tenderness, juiciness, and overall acceptability in loin tended to be highest in QG 1++, and those of juiciness and overall acceptability tended to be lowest in QG 2, although no statistical difference was detected. Previous studies reported that flavor, tenderness, juiciness, and overall acceptability of loin were better in higher QGs (Jo et al., 2013; Lim et al., 2014). The juiciness and overall acceptability were positively correlated with QG, MS, and fat content in loin. All sensory characteristics were higher in loin than those in rump. Similar findings were observed by Legako (2015), who showed higher sensory characteristics in longissimus lumborum than those in gluteus medius muscle. Previous study has indicated that tenderness and juiciness are positively affected by IMF content (Renand et al., 2001). Therefore, the higher tenderness, juiciness, and overall acceptability values in QG $1++$ and the higher sensory traits in loin than those in rump may be, in part, due to higher fat content. Overall, our results demonstrate that $\mathrm{QG}$ is tightly linked to sensory traits.
Nucleotide content is often considered as an important meat palatability factor as IMP enhances an umami taste (Aliani and Farmer, 2005). In this study, AMP and IMP contents in loin and rump did not differ significantly among QGs. Similarly, Lim et al. (2014) reported that AMP content in Korean cattle loin does not differ among QGs $(1++, 1+, 1$, and 2). However, in their study, IMP content increased with decreasing QG. Interestingly, the IMP content was significantly lower in loin than that in rump, which is in agreement with other study showing lower IMP content in loin than that in rump (Cho et al., 2007). Hypoxanthine is an important component in the formation of meat flavor and may impart a bitter flavor to the meat by conjugating with other free amino acids and some dipeptides (Tikk et al., 2006). Our results show that hypoxanthine content was highest in QG 2 and lowest in QG 1++ in both loin and rump. However, hypoxanthine content was significantly higher in loin than that in rump. Correlation analyses revealed that none of the nucleotides (AMP, IMP, inosine, or hypoxanthine) were correlated with any of the sensory traits. Thus, nucleotide content in beef may not be a major factor determining meat palatability.

Muscle collagen content affects meat tenderness (Kim 
Table 12. Pearson correlation coefficient between carcass traits and chemical composition, and sensory characteristics and amino acid contents of loin in Korean cattle steers

\begin{tabular}{|c|c|c|c|c|c|c|c|c|c|c|c|c|c|c|c|c|}
\hline Item & Ala & Arg & Cys & Glu & Gly & His & iLe & Leu & Lys & Met & Phe & Pro & Ser & Thr & Tyr & Val \\
\hline $\begin{array}{l}\text { Slaughtering } \\
\text { age }\end{array}$ & 0.05 & -0.15 & 0.13 & 0.05 & 0.05 & -0.002 & 0.15 & 0.17 & 0.18 & 0.12 & 0.05 & 0.10 & 0.15 & -0.08 & 0.14 & 0.14 \\
\hline Carcass weight & 0.05 & -0.10 & 0.16 & 0.23 & -0.08 & 0.09 & 0.18 & 0.20 & 0.13 & 0.23 & -0.01 & 0.25 & 0.17 & -0.08 & 0.19 & 0.23 \\
\hline LM area & -0.11 & -0.14 & 0.27 & 0.11 & -0.25 & -0.14 & 0.26 & $0.33^{*}$ & 0.12 & $0.29 *$ & -0.06 & 0.11 & 0.11 & 0.15 & 0.28 & 0.26 \\
\hline Fat thickness & -0.11 & -0.01 & -0.05 & $-0.30 *$ & -0.21 & -0.16 & -0.09 & -0.08 & -0.16 & -0.13 & 0.11 & -0.08 & -0.14 & -0.01 & -0.01 & -0.04 \\
\hline Marbling & -0.12 & -0.15 & 0.10 & 0.05 & $-0.38^{* *}$ & $-0.43 * *$ & $0.36^{*}$ & $0.43 * *$ & 0.26 & 0.22 & 0.28 & 0.13 & 0.03 & 0.04 & $0.34 *$ & $0.31 *$ \\
\hline Quality grade & -0.14 & -0.18 & 0.14 & -0.01 & $-0.37^{*}$ & $-0.48^{* *}$ & $0.37^{* *}$ & $0.44 * *$ & 0.25 & 0.25 & 0.25 & 0.09 & 0.03 & 0.05 & $0.37 * *$ & $0.31^{*}$ \\
\hline Yield grade & 0.07 & -0.04 & 0.22 & 0.18 & 0.04 & 0.07 & 0.09 & 0.10 & 0.15 & 0.13 & -0.21 & 0.09 & 0.11 & 0.11 & 0.02 & 0.03 \\
\hline Yield index & 0.05 & -0.01 & 0.09 & 0.24 & 0.14 & 0.08 & 0.12 & 0.13 & 0.15 & 0.15 & -0.11 & 0.04 & 0.12 & 0.08 & 0.05 & 0.06 \\
\hline Meat color & -0.03 & -0.07 & -0.16 & -0.06 & 0.04 & 0.19 & -0.20 & -0.22 & -0.23 & -0.15 & -0.23 & 0.07 & -0.13 & -0.09 & -0.26 & -0.23 \\
\hline Texture & 0.25 & 0.15 & 0.05 & 0.06 & $0.37^{*}$ & $0.57 * * *$ & $-0.34 *$ & $-0.41 * *$ & -0.16 & -0.22 & -0.13 & 0.19 & 0.02 & -0.14 & $-0.47 * *$ & -0.26 \\
\hline Maturity & 0.05 & 0.11 & -0.14 & -0.01 & 0.07 & -0.04 & 0.04 & 0.06 & 0.06 & 0.01 & 0.09 & -0.18 & -0.002 & 0.20 & 0.05 & -0.002 \\
\hline Moisture & $0.31^{*}$ & 0.04 & -0.15 & -0.10 & $0.47 * *$ & $0.53 * * *$ & -0.22 & $-0.30^{*}$ & -0.14 & -0.10 & -0.26 & -0.003 & 0.09 & -0.13 & $-0.33 *$ & -0.19 \\
\hline Protein & 0.17 & 0.13 & -0.14 & -0.16 & $0.42 * *$ & $0.30 *$ & -0.17 & -0.24 & -0.15 & -0.06 & -0.22 & -0.20 & 0.04 & 0.04 & -0.16 & -0.16 \\
\hline Fat & $-0.33^{*}$ & -0.06 & 0.15 & 0.06 & $-0.50 * * *$ & $-0.51 * * *$ & 0.17 & 0.25 & 0.10 & 0.06 & 0.24 & 0.02 & -0.14 & 0.08 & $0.29^{*}$ & 0.14 \\
\hline Cooking loss & 0.27 & -0.01 & 0.10 & 0.10 & $0.39^{* *}$ & 0.47 & -0.23 & $-0.30 *$ & -0.07 & $-0.31^{*}$ & -0.19 & 0.19 & 0.13 & -0.23 & $-0.43^{* *}$ & -0.24 \\
\hline Shear force & -0.04 & 0.07 & -0.09 & 0.02 & 0.06 & -0.01 & -0.16 & -0.18 & -0.13 & -0.17 & -0.28 & -0.25 & -0.25 & 0.16 & -0.17 & -0.21 \\
\hline $\mathrm{pH}$ & $0.38 * *$ & -0.10 & -0.14 & -0.03 & 0.22 & $0.64 * * *$ & -0.15 & -0.19 & -0.06 & -0.04 & 0.05 & $0.40 * *$ & 0.20 & $-0.32 *$ & $-0.34 *$ & 0.002 \\
\hline $\mathrm{L}^{*}$ & 0.08 & -0.08 & 0.16 & -0.06 & -0.09 & -0.06 & 0.23 & 0.25 & 0.24 & 0.21 & $0.29 *$ & $0.39 * *$ & 0.23 & -0.14 & 0.19 & 0.27 \\
\hline$a^{*}$ & -0.13 & -0.08 & -0.07 & $0.31 *$ & -0.26 & -0.11 & 0.02 & 0.05 & 0.02 & -0.01 & 0.08 & 0.15 & 0.01 & -0.10 & 0.11 & 0.09 \\
\hline$b^{*}$ & -0.13 & -0.11 & -0.12 & 0.19 & $-0.29^{*}$ & -0.27 & 0.14 & 0.16 & 0.11 & 0.07 & 0.20 & 0.14 & -0.01 & -0.12 & 0.20 & 0.16 \\
\hline Tenderness & 0.28 & -0.14 & $0.60^{*}$ & $0.72 * *$ & -0.04 & $-0.65^{*}$ & $0.67 *$ & $0.77 * *$ & $0.75 * *$ & $0.63 *$ & 0.14 & $0.72 * *$ & $0.58 *$ & -0.02 & $0.70^{*}$ & $0.72 * *$ \\
\hline Juiciness & 0.13 & -0.14 & 0.52 & $0.68^{*}$ & -0.30 & $-0.66 *$ & 0.45 & 0.56 & 0.48 & 0.37 & 0.18 & $0.82 * *$ & 0.39 & -0.06 & 0.43 & 0.48 \\
\hline Flavor & 0.52 & -0.35 & 0.38 & 0.47 & -0.18 & -0.19 & $0.70^{*}$ & $0.75^{* *}$ & $0.82 * *$ & $0.62 *$ & -0.18 & 0.48 & 0.52 & -0.12 & $0.63^{*}$ & $0.63 *$ \\
\hline $\begin{array}{l}\text { Overall } \\
\text { acceptability }\end{array}$ & 0.18 & -0.23 & 0.43 & $0.60^{*}$ & -0.43 & -0.50 & 0.42 & 0.51 & 0.45 & 0.31 & 0.08 & $0.78^{* *}$ & 0.32 & -0.11 & 0.34 & 0.39 \\
\hline
\end{tabular}

LM, longissimus muscle.

$* \mathrm{p}<0.05 ; * * \mathrm{p}<0.01 ; * * * \mathrm{p}<0.001$.

and Lee, 2003). In loin, we observed higher contents of total, soluble, and insoluble collagen in QG $1++$ than those in QG 1. Our correlation analyses revealed that content of all three collagens was correlated with sensory traits, including tenderness, juiciness, and overall acceptability. The relationship between collagen contents and tenderness is controversial; another study show no relationship between collagen contents and tenderness (Field et al., 1997), whereas others have shown lower collagen contents with better QG (Ryu et al., 1994).

In the case of free amino acids, isoleucine, leucine, and tyrosine contents in loin were highest in QG 1++ and lowest in QG 2. In addition, glutamic acid content did not differ significantly among the four QGs in loin or rump. In addition, the glutamic acid, isoleucine, leucine, lysine, serine, tyrosine, and valine contents were higher in loin than those in rump, whereas arginine, cysteine, glycine, histidine, and threonine contents were higher in rump than those in loin. Alanine, arginine, cysteine, glycine, lysine, methionine, phenylalanine, serine, threonine, and valine contents did not differ among the four QGs. Lim et al. (2014) reported that threonine and alanine contents in Korean cattle loin were highest in QG 2 among QGs $(1++, 1+, 1$, and 2). Free amino acids can influence flavor, taste, and aroma formation in meat during storage (Jo et al., 2012). Our correlation analyses revealed that isoleucine, leucine, lysine, methionine, tyrosine, and valine contents in loin were correlated with flavor. In addition, some amino acids, such as glutamic acid and proline, were significantly associated with sensory traits, including tenderness, juiciness, and overall acceptability. Therefore, our results partially match a previous report on the association between amino acid content and beef taste. In that study, asparagine, serine, threonine, glycine, alanine, and glutamic acid were related to a sweet taste, whereas isoleucine, leucine, valine, methionine, phenylalanine, histidine, arginine, and proline were related to a bitter taste in meat (Sforza et al., 2001). Shahidi et al. (1986) reported that the particular amino acids, such as glutamic acid, may function as flavor enhancers, to enhance the flavor contribution of other agents. Jo et al. (2012) reported similarly that glutamic acid can enhance an umami taste by reacting with IMP. Further study is required to understand the functional significance of the relationships between individual amino acids and beef palatability.

Taken together, this study confirms that MS and IMF content are major positive determinants of QG in Korean cattle beef. Numeric values of tenderness, juiciness, and overall acceptability in loin tended to be highest in QG 1++, and those of juiciness and overall acceptability tended to be lowest in QG 2. Juiciness and overall acceptability were strongly correlated with QG. Our results demonstrate that QGs are linked to sensory traits. However, the nucleotide contents including IMP may not be a major factors 
determining meat palatability of Korean cattle beef in this study. Glutamic acid and proline were significantly associated with tenderness, juiciness, and overall acceptability, although they did not differ significantly among QGs.

\section{CONFLICT OF INTEREST}

We certify that there is no conflict of interest with any financial organization regarding the material discussed in the manuscript.

\section{ACKNOWLEDGMENTS}

This study was supported by grants from Cargill Agri Purina Inc. and the Next-Generation BioGreen 21 Program (No. PJ01114001), Rural Development Administration, Republic of Korea.

\section{REFERENCES}

Aliani, M. and L. J. Farmer. 2005. Precursors of chicken flavor: II. Identification of key flavor precursors using sensory methods. J. Agric. Food Chem. 53:6455-6462.

AOAC. 1996. Official Methods of Analysis. 15th ed. Association of Official Analytical Chemists, Washington, DC, USA. pp. 210-219.

Cho, S., G. Kang, P. Seong, S. Kang, K. Park, Y. Kim, and B. Park. 2013. Physico-chemical meat quality and nutritional composition of 10 cuts for Hanwoo steer beef of quality grade 1. Ann. Anim. Resour. Sci. 24:147-156.

Cho, S. H., J. Kim, B. Y. Park, P. N. Seong, G. H. Kang, J. H. Kim, S. G. Jung, S. K. Im, and D. H. Kim. 2010. Assessment of meat quality properties and development of a palatability prediction model for Korean Hanwoo steer beef. Meat Sci. 86:236-242.

Cho, S. H., J. H. Kim, P. N. Seong, Y. M. Cho, W. T. Chung, B. Y. Park, M. O. Chung, D. H. Kim, J. M. Lee, and C. N. Ahn. 2008. Physico-chemical meat quality properties and nutritional composition of Hanwoo steer beef with $1++$ quality grade. Korean J. Food Sci. Anim. Resour. 28:422-430.

Cho, S. H., J. H. Kim, P. N. Seong, Y. H. Choi, B. Y. Park, Y. J. Lee, T. S. In, S. Y. Chun, and Y. K. Kim. 2007. Cholesterol, free amino acid, nucleotide-related compounds, and fatty acid composition of Korean Hanwoo bull beef. Korean J. Food Sci. Anim. Resour. 27:440-449.

Cho, S., P. Seong, G. Kang, S. Jung, H. Kim, B. Park, S. M. Kang, and D. Kim. 2011. Comparison of volatile flavor profiles for Hanwoo and imported beef. Ann. Anim. Resour. Sci. 22:42-51.

Dow, D. L., B. R. Wiegand, M. R. Ellersieck, and C. L. Lorenzen. 2011. Prediction of fat percentage within marbling score on beef longissimus muscle using 3 different fat determination methods. J. Anim. Sci. 89:1173-1179.

Durnford, E. and F. Shahidi. 1998. Flavour of fish meat. In: Flavour of Meat, Meat Products and Seafoods, 2nd ed. (Ed. F. Shahidi). Blackie Academic and Professional, London, UK. pp. 131-158.
Field, R., R. McCormick, V. Balasubramanian, D. Sanson, J. Wise, D. Hixon, M. Riley, and W. Russell. 1997. Tenderness variation among loin steaks from $\mathrm{A}$ and $\mathrm{C}$ maturity carcasses of heifers similar in chronological age. J. Anim. Sci. 75:693699

Huffman, K. L., M. F. Miller, L. C. Hoover, C. K. Wu, H. C. Brittin, and C. B. Ramsey. 1996. Effect of beef tenderness on consumer satisfaction with steaks consumed in the home and restaurant. J. Anim. Sci. 74:91-97.

Jayasena, D. D., S. Jung, H. J. Kim, A. U. Alahakoon, K. C. Nam, and C. Jo. 2014. Effect of sex on flavor-related and functional compounds in freeze-dried broth made from Korean native chicken. Korean J. Food Sci. Anim. Resour. 34:448-456.

Jayasena, D. D., S. Jung, H. J. Kim, Y. S. Bae, H. I. Yong, J. H. Lee, J. G. Kim, and C. Jo. 2013. Comparison of quality traits of meat from Korean native chickens and broilers used in two different traditional Korean cuisines. Asian Australas. J. Anim. Sci. 26:1038-1046.

Jo, C., S. H. Cho, J. Chang, and K. C. Nam. 2012. Keys to production and processing of Hanwoo beef: a perspective of tradition and science. Anim. Front. 2:32-38.

Jo, C., D. D. Jayasena, D. G. Lim, K. H. Lee, J. J. Kim, J. S. Cha, and K. C. Nam. 2013. Effect of intramuscular fat content on the meat quality and antioxidative dipeptides of Hanwoo beef. Korean J. Food Nutr. 26:117-124.

Jung, S., Y. S. Bae, H. J. Kim, D. D. Jayasena, J. H. Lee, H. B. Park, K. N. Heo, and C. Jo. 2013a. Carnosine, anserine, creatine, and inosine 5 '-monophosphate contents in breast and thigh meats from 5 lines of Korean native chicken. Poult. Sci. 92:3275-3282.

Jung, S., K. C. Nam, K. H. Lee, J. J. Kim, and C. Jo. 2013b. Meat quality traits of Longissimus dorsi muscle from carcasses of Hanwoo steers at different yield grades. Korean J. Food Sci. Anim. Resour. 33:305-316.

Kim, C. J. and E. S. Lee. 2003. Effects of quality grade on the chemical, physical and sensory characteristics of Hanwoo (Korean native cattle) beef. Meat Sci. 63:397-405.

KAPE. 2013. Report of business for animal products grading. Korea Institute for Animal Products Quality Evaluation, Gunpo, Korea.

Lee, S. M., J. Y. Kim, and E. J. Kim. 2012. Effects of stocking density or group size on intake, growth, and meat quality of Hanwoo steers (Bos Taurus coreanae). Asian Australas. J. Anim. Sci. 25:1553-1558.

Legako, J. F., J. C. Brooks, T. G. O'Quinn, T. D. J. Hagan, R. Polkinghorne, L. J. Farmer, and M. F. Miller. 2015. Consumer palatability scores and volatile beef flavor compounds of five USDA quality grades and four muscles. Meat Sci. 100:291-300.

Lim, D. G., J. S. Cha, C. Jo, K. H. Lee, J. J. Kim, and K. C. Nam. 2014. Comparison of physicochemical and functional traits of Hanwoo steer beef by the quality grade. Korean J. Food Sci. Anim. Resour. 34:287-296.

Moon, S. S., I. H. Hwang, S. K. Jin, J. G. Lee, S. T. Joo, and G. B. Park. 2003. Carcass traits determining quality and yield grades of Hanwoo steers. Asian Australas. J. Anim. Sci. 16:1049-1054.

Moon, S. S., H. S. Yang, G. B. Park, and S. T. Joo. 2006. The relationship of physiological maturity and marbling judged according to Korean grading system to meat quality traits of Hanwoo beef females. Meat Sci. 74:516-521. 
National Livestock Cooperatives Federation (NLCF). 1998 Korean carcass grading standard. National Livestock Cooperatives Federation, Seoul.

Ozawa, S., T. Mitsuhashi, M. Mitsumoto, S. Matsumoto, N. Itoh, K. Itagaki, Y. Kohno, and T. Dohgo. 2000. The characteristics of muscle fiber types of longissimus thoracis muscle and their influences on the quantity and quality of meat from Japanese black steers. Meat Sci. 54:65-70.

Renand, G., B. Picard, C. Touraille, P. Berge, and J. Lepetit. 2001. Relationships between muscle characteristics and meat quality traits of young Charolais bulls. Meat Sci. 59:49-60.

Ryu, Y. S., M. Lee, and K. C. Ko. 1994. A study on the quality comparison of Korean native cattle beef in relation to Korean quality grading system and imported beef. Kor. J. Anim. Sci. 36:340-346.

Sarriés, M. V. and M. J. Beriain. 2006. Colour and texture characteristics in meat of male and female foals. Meat Sci. 74:738-745.
Savell, J. W., R. E. Branson, H. R. Cross, D. M. Stiffler, J. W. Wise, D. B. Griffin, and G. C. Smith. 1987. National consumer retail beef study: palatability evaluations of beef loin steaks that differed in marbling. J. Food Sci. 52:517-519.

Sforza, S., A. Pigazzani, M. Motti, C. Porta, R. Virgili, G. Galaverna, A. Dossena, and R. Marchelli. 2001. Oligopeptides and free amino acids in Parma hams of known cathepsin B activity. Food Chem. 75:267-273.

Shahidi, F., L. J. Rubin, L. A. D'Souza, R. Teranishi, and R. G. Buttery. 1986. Meat flavor volatiles: A review of the composition techniques of analysis, and sensory evaluation. Crit. Rev. Food Sci. Nutr. 24:141-243.

Shorthose, W. R. and P. V. Harris. 1990. Effect of animal age on the tenderness of selected beef muscles. J. Food Sci. 55:1-8.

Tikk, M., K. Tikk, M. A. Tørngren, L. Meinert, M. D. Aaslyng, A. H. Karlsson, and H. J. Andersen. 2006. Development of inosine monophosphate and its degradation products during aging of pork of different qualities in relation to basic taste and retronasal flavor perception of the meat. J. Agric. Food Chem. 54:7769-7777. 